\title{
МОТИВИСАЊЕ ЗАПОСЛЕНИХ У МЕДИЈСКИМ ОРГАНИЗАЦИЈАМА РЕПУБЛИКЕ СРБИЈЕ
}

\author{
Владан Петровић
}

\begin{abstract}
Апстракт: Мотивисање запослених је базични проблем са којим се суочава данашње економско окружење, а мотивација је важан део процеса управљања. Менаџери треба да изграде истинску позитивну структуру подстицаја која сваком појединцу пружа ону врсту мотивације која му је потребна. Појединци су јединствени и групне норме се разликују од једне организације до друге: оно што може мотивисати једну групу запослених, може имати сасвим супротан ефекат на другу групу. Наведено је посебно изражено у медијским организацијама данас, будући да су константно упослени од почетка пандемије вируса Covid-19. Циљ рада је приказати могуће начине мотивације запослених у медијским организацијама Републике Србије.
\end{abstract}

Кључне речи: мотивација, запослени, медијске организације, Covid-19

\section{УВОД}

Многи сматрају да је новац највећи мотиватор! Изгледа, ипак, да су јачи они мотиватори који нису везани за новац. Џери Мек Адамс

Организације, без обзира на индустрију и величину, теже стварању јаких и позитивних односа са својим запосленима. Међутим, запослени имају различите конкурентне потребе које су вођене различитим мотиваторима. На пример, неки запослени су мотивисани наградама, док се други фокусирају на постигнуће или сигурност, лични напредак. Стога је од суштинске важности да организација и њени менаџери разумеју шта заиста мотивише њене запослене ако намеравају да максимизирају организациони учинак.

1 Fakultet za hotelijerstvo i turizam u Vrnjačkoj Banji, Univerzitet u Kragujevcu e-mail:vladanpetrovicvb@putlook.com 
Како би адекватно и успешно пословало, свако предузеће мора пронаћи оптималну комбинацију материјалних и нематеријалних подстицаја за своје запослене. У јавности је често симплификована проблематика појма мотивације за рад и најчешће се у предузећима своди на материјално награђивање запосленог. Наиме, задовољство запослених проистиче не само из материјалних подстицаја, већ и из широког спектра нематеријалних фактора. Успешна предузећа у свету на своје запослене гледају као на примарни развојни ресурс, а њихова мотивација и задовољство постају основ сваке савремене организације. Акценат се ставља на активно управљање њиховим потенцијалима, док се у контексту унапређења употребе људског фактора развијају различите схеме за увећање позитивне мотивације за рад. При спровођењу наведеног посебно се инсистира на задовољству послом, као главном показатељу мотивисаности запослених, стимулативности самог посла и укупне радне димензије. Разумевање проблематике задовољства послом и мотивације запослених је од суштинског значаја за осмишљавање и дизајнирање једног радног места, организацијске климе и културе, политике пословања предузећа, система напредовања и награђивања, као и стила руковођења (Вукашин, 2021).

У савременом, глобалном пословном окружењу, предузећа своју конкурентску предност могу успешно градити само на једном ресурсу - људском; на талентима, знањима и мотивацији својих запослених. Запослени су често, не само највреднији, већ и најскупљи организацијски ресурс, па управљање њима мора бити дугорочно и стратешки одлично испланирано. Мотивација и награђивање су два међусобно условљена процеса и модерна предузећа овом питању све више посвећују пажњу. Свесност о директној вези између мотивације запослених и задовољства са једне, и остварених пословних резултата и понашања на послу са друге стране, многа предузећа наводи да проблематици награђивања запослених прилазе студиозно и са великом озбиљношћу. Основна сврха свих мотивационих фактора је да створе окружење у коме су људи спремни да раде са жаром, иницијативом, интересовањем и ентузијазмом, са високим личним и групним задовољством, са осећајем одговорности, лојалности и самопоуздања како би остварили свој лични као и организационе циљеве. 


\section{МЕТОДОЛОГИЈА РАДА}

Предмет рада представља значај мотивисања запослених и могући начини за то у медијским организацијама Републике Србије. Циљ рада је приказати могуће начине мотивације запослениху медијским организацијама Републике Србије. У те сврхе употребљене су научно-истраживачке методе анализе и синтезе, као и индукције и дедукције, као и компаративна метода. Радје конципиран као приказ тренутне ситуације у медијским организацијама наше државе, са предлозима за њено побољшање.

\section{Традиционалне и савремене теорије мотивације}

Мотивација је замишљена као витално оруђе за покретање радника да дају све од себе вољно и са ентузијазмом у правцу реализације организационих циљева док у исто време постижу задовољство послом. Другим речима, јачање мотивације на радном месту је моћна снага запослених да остваре постављене циљеве.

Традиционалне теорије мотивације фокусирају се на специфичне елементе који мотивишу запослене у потрази за организационим перформансама. На пример, теорија мотива и потреба (Maslov, 1943) наводи да запослени имају пет нивоа потреба (физиолошке, безбедносне, социјалне, его и самоактуализујуће), док теорија правичности и правде наводи да запослени теже једнакости између себе и других. запослених (Adams, 1963; 1965). Међутим, тренутна истраживања мотивације запослених су више међудисциплинарна и обухватају области као што су неуронаука, биологија и психологија.Чини се да тренутна истраживања имају за циљ да споје и револуционишу традиционалне теорије мотивације у свеобухватнију теорију која обухвата традиционалне перспективе менаџмента, људских ресурса, понашања организације са новим перспективама у неуронауци, биологији и психологији. На пример, Лоренс и Нохрија (2002) користе међудисциплинарне перспективе да објасне како је људска природа темељ мотивације запослених. Они тврде да је у људској природи да запослени поседују четири нагона - нагон за стицањем, повезивањем, разумевањем и одбраном - и ови нагони су основа за мотивацију запослених. Њихово истраживање такође наводи организационе полуге које испуњавају ове нагоне. Системи награђивања испуњавају нагон за стицањем, култура испуњава нагон за повезивањем, дизајн посла испуњава нагон да се схвати, а процеси управљања учинком и 
алокације ресурса испуњавају нагон за одбраном (Lawrence \& Nohria, 2002). Када се ове организационе полуге користе за испуњавање покрета и мотивације запослених, организациони учинак је максимизиран.

Тренутни развој теорије мотивације заснива се на шаблону конвенционалне квантитативне анализе (нпр. анализа вишеструке регресије, моделирање структурних једначина), што је очигледно доминантан начин спровођења друштвених истраживања данас (Fiss, 2011; Ragin, 2008). Пошто су квантитативни истраживачи заинтересовани за контекст и холистичко разумевање друштвених феномена, тенденција је да се размишља у терминима комбинација и конфигурација скупа релевантних варијабли, који се често називају "случајни рецепти“, где се узрочно релевантни услови комбинују да би објаснили како је дати исход постићи. Приступ теорији скупова омогућава конфигурационо размишљање и сложену узрочност, што допуњује конвенционалну квантитативну анализу. Теоријски приступ открива како се различити услови комбинују и да ли постоји само једна комбинација или неколико различитих комбинација услова (узрочних рецепата) које могу да генеришу исти исход (Ragin, 2008).

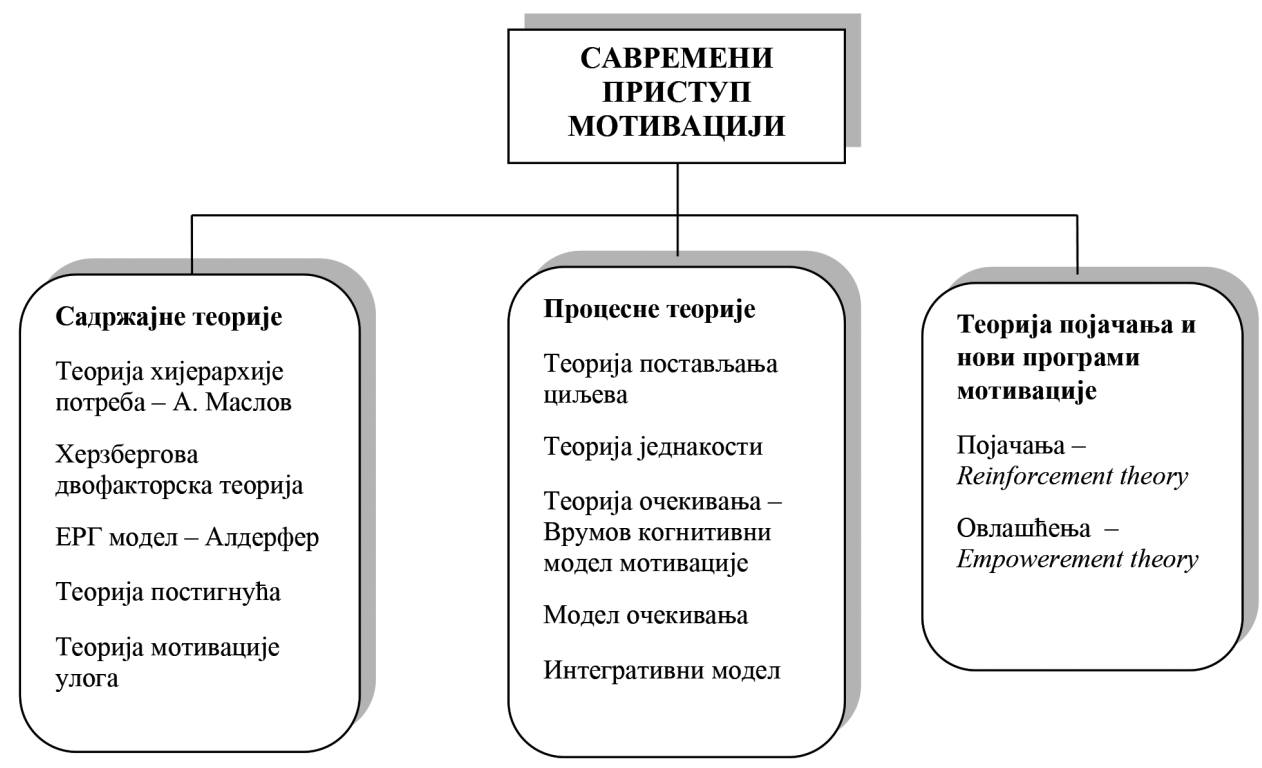

Шема 1. Систематизација мотивацијских теорија (аутор, према Lee \& Raschke, 2016) 


\section{Медијске организације у савременом добу}

У транзиционом друштву заснованом на профиту и природа вести се мења, подривајући тежњу професионалних новинара за објективношћу и истинитошћу информација. Медијски сектор није изузетак од овог процеса промене. Сведоци смо да данашњи медији, нажалост, заступају сензационалистички приступ, који их претвара у таблоиде и тзв. „жуту штампу“. Доминантни таблоидни дискурс није заобишао ни велике медијске куће, па су знатно слабији тонови озбиљне штампе и новинарског извештавања. Неретко је да у многим државама политика утиче на начин на који медији извештавају, па се и тако нарушава основни новинарски етички кодекс.

Као и у осталим типовима организација, запослени у медијским организацијама представљају њихов најважнији ресурс. Уколико су запослени задовољни условима на свом радном месту, ефикасније и са више ентузијазма обављају свој посао, а самим тим расте популарност медија у ком раде. Међутим, наведена ситуација о таблоидизацији свих медија, не одговара већини професионалних новинара који су вредно радили на изградњи своје каријере. Самим тим, њихова мотивација опада и временом се почињу кретати „линијом мањег отпора“ и следити наметнути ток ствари (Duminică\&Popescu, 2012).

Појава пандемије вируса Covid-19 је знатно погоршала ситуацију. У овим околностима, медији и новинарство представљају кључну тачку у јавној сфери, будући да специфичним приступом проблему граде оквир у којем се целокупна јавност односи према најважнијим питањима у вези са пандемијом. Иако се улога медија у здравственој кризи схвата тек као индиректна у односу на улогу државе или медицинске струке, јавно-интересна оријентација медија представља темељ у решавању кризе, али и очувању демократије у друштву које је њоме захваћено.

Када је у марту 2020. године пандемија захватила и Републику Србију, то је у великој мери утицало и на рад штампаних и дигиталних медија. Од почетка пандемије, Влада Републике Србије увела је неке веома рестриктивне мере на државном нивоу. Неке од њих су биле: рад од куће, државни органи су престали да раде са грађанима, полицијски час, неке основне услуге биле су недоступне, итд. Комплетно затварање државе имало је последице и на рад медија и новинара, којима је осим страха за живот било неопходно помоћи и у очувању радног места. „Појава вируса довела је до тесне сарадње између државе и медија, а све у циљу очувања јавног здравља" (Лаковић Конатар, 2020: 7). 
Намеће се закључак да је у савременом добу, посао запослених у медијским организацијама знатно отежан. У складу са тим, потребно је уложити више напора како би запослени били мотивисани да свој посао и даље обављају квалитетно и ентузијастично. Дакле, неопходно је обезбедити им, превасходно, осећај сигурности у сопствено запослење, затим да су будући изгледи и имиџ медијске организације стабилни, као и да је њихов креативни приступ послу и даље могућ, а бенефиције загарантоване (Koslowski, 2010).

Свеукупно задовољство запослених на радном месту у медијској организацији је од виталног значаја за добробит радника. Погрешно је веровати да је висока плата, која укључује либералне погодности, главни фактор задовољства послом појединаца. Уместо тога, у пракси је утврђено да задовољство послом запослених зависи од низа фактора као што су моћ, положај, слобода, престиж, природа посла, радно време, учешће у доношењу одлука, награде, однос са колегама и другима у организацији, стручност, могућност усавршавања и напредовања, сигурност посла и будући изгледи заједно са имиџом организације (Mishra, 2013).

\section{Медијске организације у Републици Србији}

У законодавству Републике Србије појам медија дефинише се у четвртом делу Закона о јавном информисању и медијима из 2014. године, у члановима 29, 30 и 31 („Сл. гласник PC", бр. 83/2014, 58/2015 и 12/2016 - аутентично тумачење). Може се запазити да се прво даје позитивна дефиниција појма медија, а затим се додатно прецизира, тј. ограничава негативном енумерацијом којом се прописује шта се не може сматрати медијима „Медијска сцена у Србији као једно од најзначајнијих обележја носи широку распрострањеност наратива окарактерисаних говором мржње, дезинформацијама и пропагандом“ (Валић Недељковић \& Јањатовић Јовановић, 2020: 7).

Република Србија има два јавна медијска сервиса, РТС са националном фреквенцијом и РТВ са регионалним дометом. Оба емитера највећи део својих прихода добијају из републичког буџета, што утиче на њихову уређивачку политику, независност и објективност. Поред државног финансирања, PTC и РТВ такође се такмиче са другим медијским кућама за део тржишта оглашавања. Српско медијско тржиште је мало и презасићено, са преко 2000 медија, колико их је регистровано код Агенције за привредне регистре (АПР). 36ог лоше регулисаног система регистрације, тачан број регистрованих медија и даље није познат. Познато је и да је више од 500 нових медија забележено у протекле две године као медији који се самостално финансирају (Максић, 2020). 
Када је реч о медијском садржају, доминира сензационалистичка и таблоидна реторика као и „ријалити“ програми који се емитују путем националних ТВ станица. Слобода медијског изражавања је у паду. Од почетка 2018. године база Независног удружења новинара Србије бележи укупно 102 напада на новинаре - од тога 7 физичких напада, 72 недозвољена притиска и 23 вербалне претње (Максић, 2020).

\section{Мотивација запослених у медијским организацијама Републике Србије и могући начини унапређивања}

Као што је раније поменуто, талас таблоидизације није заобишао ни медије у нашој држави. То за последицу има опадање квалитета медијског садржаја и неповерење грађана у медијске организације (Ansell, 2005). Ако грађани немају поверења у медијске организације, како ће запослени у њима имати и бити мотивисани за рад?

Наведено питање може имати одговор у синтези традиционалних и савремених теорија мотивације, будући да у тренутној, незавидној економској ситуацији и материјални подстицаји могу имати велику улогу у мотивисаности запослених. Свакако, не треба се задржати на томе, већ је потребно истражити шта је појединцима из колектива потребно како би надаље успешно обављали своје задатке. Позитивна култура рада доноси жељени ниво задовољства запослених на свим нивоима. У окружењу без стреса, запослени се такође осећају задовољнијим. Дакле, потребно је умањити стресне ситуације, како би се постигли одређени циљеви (Fidler, 2004).

Постоје различити начини на које се запослени награђују. Ово увелико доприноси уливању задовољства запослених и представља основу за ефикасан рад. То је механизам којим се даље вештине потребне за обављање задатака могу пренети на запослене путем специјализоване обуке (Luthans, 1998).

У тренутним условима, свим запосленим у медијским организацијама наше државе могуће је понудити неке од следећих начина мотивације:

- могућност обликовања посла;

- флексибилне облике радног времена;

- делегирање овлашћења;

- унапређена комуникација;

- повратне информације о њиховом раду;

- признавање успеха;

- могућност усавршавања. 
Под могућношћу обликовања посла, подразумева се давање слободе медијским радницима да самостално одлучују у којим пројектима желе учествовати, која тематика их интересује, као и пружити им могућност самосталног истраживачког рада. Запослени који има, условно речено, моћ да дизајнира свој посао, учиниће то на много креативнији начин и ефикасније од запосленог коме су наметнуте теме које истражује или задаци које обавља. Свакако, у наведеном треба имати на уму и то да циљеви организације буду задовољени.

Данас је флексибилни облик радног времена постао свакодневица скоро свих нас. Пандемија је многе организације навела да преиспитају однос према томе и све је више запослених који раде од куће. Када су запослени у медијским организацијама у питању, потребно је повести рачуна о тзв. синдрому сагоревања (енгл. burnout) који се јавља код све већег броја оних који раде од куће. Недостатак социјалних интеракција и усмереност на рад „у четири зида“ код људи који нису добро организовани може произвести извесне потешкоће. На тај начин флексибилно радно време постаје демотиватор. Неопходно је испитати (месечно или квартално) задовољство запослених у том смислу, како једноставно не би посао обављали рутински и без мотивисаности за напредак. Наведено се може споровести путем анонимних анкета које се могу поделити запосленима или кроз индивидуалне разговоре са њима.

Делегирање овлашћења представља модеран облик мотивисања запослених и највиши је ниво партиципације запослених у учествовању у доношењу одлука и спровођењу истих. Као и са партиципацијом у одлучивању, потребно је да запослени у медијским организацијама имају свест о томе да њихове одлуке имају последице, а да исходи са собом носе и одговорност.

Интерна комуникација је кључ успеха сваке организације, па и медијских. Унапређење комуникације треба да се одвија на свим нивоима у медијској организацији - како на линији топ менаџмент - запослени, тако и међу самим запосленима. Нарочито данас, одговорно извештавање у мноштву догађаја које треба новинарски адекватно обрадити и представити јавности, немогуће је постићи без добро организоване комуникацијске мреже између запослених у медијима. „Од састанка на коме се планира расподела дневних задатака, до одласка новинара на терен ради прикупљања материјала или обављања разних новинарских задужења, читав медијски тим мора бити комуникацијски ангажован како би медијски процес од планирања задатака до извештавања публике, као крајњег циља информативних медија, био успешно реализован" (Љајић \& Дојчиновић, 2021: 28). У савремено доба различити онлајн алати могу помоћи у успостављању ефикасне интерне комуникације на свим нивоима медијске организације. Уколико успешна комуникација из- 
остаје, запослени нису мотивисани да ваљано спроводе своје задатке, већ су усредсређени на проналажење извора неспоразума и решавање насталих међусобних конфликата.

Повратне информације о раду запослених (енгл. feedback) су од релевантног значаја за њихову даљу мотивисаност за ефикасно испуњавање обавеза и обављање задатака. Уколико запослени не добија повратне информације о обављеном послу и сопственом учинку и перформансама, не може бити сигуран да ли свој посао обавља на начин на који то треба да чини, треба ли да настави у том правцу, да ли у нечему греши и треба ли шта променити. Наведено може знатно утицати на смањење самопоуздања код запослених и демотивисати их за пружање пуних потенцијала.

Признавање успеха запосленом у медијској организацији може се учинити на више начина:

- истицањем његовог успешно обављеног задатка уз поштовање етичког кодекса;

- бенефицијама;

- јавним похвалама.

Од релевантног значаја је да су програми признавања успеха транспарентни, како би свим запосленима било јасно које се понашање и исход рада хвали и признаје у организацији. Данас би у медијским организацијама то, свакако, требало да буде објективност у извештавању, поштовање Кодекса новинара, као и прибављање података из проверених извора. Такође, треба награђивати и иновативне приступе раду у медијима, као и оспособљеност медијског радника да ефективно ради у тренутно веома неповољном окружењу.

Могућност усавршавања је снажан мотиватор код многих запослених у медијским организацијама. Сазнање да медијска организација подржава напредовање запослених у том смислу, чини ту организацију пожељном за младе људе жељне нових искустава. То се може остварити кроз програме обуке осмишљене унутар саме организације или слање запослених на семинаре који их интересују, а у сфери су обављања њиховог посла.

Сви могући облици мотивисања запослених у медијским организацијама имају упориште у основним начинима мотивисања запослених у различитим типовима организација. Међутим, у савремено доба је потребно мотивисати запослене у медијским организацијама да поступају етички и не баве се спиновањем или полуистинама, већ да потраже инспирацију у свакодневном животу. Такође, потребно је неговати свест код запослених да њихова реч има одређену моћ у обликовању схватања догађаја у јавности, те да нема места за сензационализам и извештаје који шире панику. 


\section{ЗАКЉУЧАК}

У савремено доба слободно тржиште економије присиљава медијске организације да поседују не само добро управљање, него такође да користе нове технологије и брину о мотивисаности својих запослених. Постављање медијске организације у прикладно окружење омогућава развој и напредак саме организације. Што је динамичније окружење, то је потребнија диференциранија структура организације. У тој сфери, менаџери треба да открију најбоље начине који би могли да подстакну запослене да с времена на време усмере понашање, јер задовољење једне потребе доводи до друге потребе и на тај начин целокупан систем напредује.

Из свега наведеног у раду закључује се да је запосленима у медијским организацијама данас потребна мотивација да свој посао обављају на исти начин као што су то чинили на почетку свог запослења, док је новим запосленима потребно пружити подршку и пример како се ефикасно обавља овај важан посао. У данашњим неизвесним економским условима, материјални подстицаји треба да буду присутни као мотиватори, али се менаџмент медијске организације не сме зауставити на томе. Од велике је важности сваком запосленом приступити као индивидуи која има своје потребе, жеље и покретаче и пронаћи начин мотивације који ће донети жељене резултате. У свему томе интерна комуникација има велику улогу, јер уколико изостане, незадовољство у колективу је неминовно и за последицу има неамбициозно обављен посао. Лоши интерперсонални односи, као и политика медијске организације да се приклања одређеним политичким захтевима или негује таблоидни дискурс, могу бити јаки демотиватори за запослене. Дакле, промене у самим медијским организацијама, нарочито у нашој држави, треба да буду корените, како би сви запослени у њима пружили свој пуни потенцијал и ефективно се бавили послом за који су се образовали. 


\section{ЛИТЕРАТУРА}

1. Adams, J.S. (1963). Towards an understanding of inequity. The Journal of Abnormal and Social Psychology, 67(5), 422-436.

2. Adams, J.S. (1965). Inequity in Social Exchange. Advances in Experimental Social Psychology, 2, 267-299.

3. Ansell, G. (2005). Introduction to Journalism. Johannesburg: Jacana Media.

4. Валић Недељковић, Д. \& Јањатовић Јовановић, М. (2020). Медијски систем у Србији обележен деловањем медија који систематично шире дезинформације, говор мржње и пропаганду. Нови Сад: Новосадска новинарска школа, Тирана: СЕЕНПМ, Љубљана: Мировни институт.

5. Вукашин, М. (2021). Радна мотивација запослених у организацији. Зборник радова Факултета техничких наукау Новом Саду, 36(10), 1724-1727.

6. Duminică, D. \& Popescu, G. (2013). Education FacingContemporary World Issues Motivational dynamics inmedia organizations. Procedia - Social and Behavioral Sciences, 76, 312-316.

7. Закон о јавном информисању и медијима, "Сл. гласник РС“, бр. 83/2014, 58/2015 и 12/2016 - аутентично тумачење.

8. Koslowski, P. (2010). Elements of a Philosophy of Management and Organization. New York: Springer

9. Лаковић Конатар, Б. (2020). Нови медији - стари проблеми: истраживање о стању у дигиталним медијима и утицају пандемије Ковид-19. Цетиње: Синдикат медија Црне Горе.

10. Lawrence, P. R. \&Nohria, N. (2002). Driven: How Human Nature Shapes Our Choices. San Francisco: Jossey-Bass.

11. Lee, M. \& Raschke, R. (2016). Understanding employee motivation and organizational performance: Arguments for a set-theoretic approach. Journal of Innovation \& Knowledge, 1(3), 162-169.

12. Luthans, F. (1998). Organisational Behaviour. Boston: Irwin McGrawHill.

13. Љајић, С. \&Дојчиновић, Н. (2021). Онлајн алати у функцији интерне комуникације у медијима. 3борник радова Филозофског факултета у Нишу, 51(1), 19-41.

14. Максић, Т. (2020). Медији и нове политике управљања интернетом. Београд: БИРН.

15. Maslow, A. (1943). A theory of human motivation.Psychological Review, 50(4),370-396. 
16. Mishra, S. (2013). Work motivational styles in media organizations. International Journal of Marketing, Financial Services \& Management Research, 2(9), 95-105.

17. Ragin, Ch. (2008). Redesigning Social Inquiry. Fuzzy Sets and Beyond. Chicago: The University of Chicago Press.

18. Fidler, R. (2004). Mediamorphosis: Razumevanje novih medija. Beograd: Clio.

19. Fiss, P.C. (2011). Building better causal theories: A fuzzy set approach to typologies in organization research.Academy of Management Journal, 54(2), 393-420. 